\title{
Books Received at the Editorial Office
}

S. Hayase and S. Munao (eds.): Cardiology - Proceedings of the VIII World Congress of Cardiology, Tokyo, Sept. 1978. Excerpta Medica, Amsterdam 1979. 1,148 pp. J. Hamer (ed.): Drugs for Heart Disease. Chapman \& Hall, London 1979. 596 p.;E 22.50. Peter F. Cohn (ed.): Diagnosis and Therapy of Coronary Artery Disease. Little, Brown,

Boston 1979. 494 pp. Raymond E. Phillips: Cardiovascular Therapy. A Systematic Approach. Vol. 1, Circulation.

Saunders, Philadelphia 1979. 741 pp.;E 20.75. H. Roskamm and M. Schmuziger (eds.): Coronary Heart Surgery. A Rehabilitation Measure.

Springer, Berlin 1979. 388 pp. Paul N. Yu and John F. Goodwin: Progress in Cardiology. Lea \& Febiger, Philadelphia 1978.

228 pp. K. Holldack and H.W. Rautenburg: Phonokardiographie (pocket book in German). Thieme,

Stuttgart 1979. 187 pp.; DM 22.80. 